movy: v 11 tomakh / AN URSR. Instytut movoznavstva; za red. I. K. Bilodida. - K.: Naukova dumka, 1970-1980.T. 6, S. 684.

27. Коротун В. М. Функції апеляційного суду через призму понятійного апарату / В. Коротун // Адвокат. 2012. № 8. C. 35-37; Korotun V. M. Funktsii apeliatsiinoho sudu cherez pryzmu poniatiinoho aparatu / V. Korotun // Advokat. 2012. № 8. S. 35-37.

\title{
A. Gaponov \\ COMPETENCE AND AUTHORITIES OF COURTS IN THE SYSTEM OF JUDICIARY IN UKRAINE (ON THE CASE OF COURT OF APPEALS)
}

The article highlights the notion of the judiciary, its main functions and provides an author's classification of the judiciary's functions into basic and auxiliary ones. The concept of the powers of the court of appeals is investigated, the author's proposals for changes to the current legislation are given.

Keywords: judiciary, functions of the judiciary, Court of Appeal, powers, competence. Стаття надійшла до редакції 07.10.2019 р.

УДК 343.983

\section{Н.В. Мітько}

\section{ПОНЯТТЯ ІНФОРМАЦЙНО-ПОШУКОВИХ СИСТЕМ ЕКСПЕРТНОЇ СЛУЖБИ МВС УКРАЇНИ У БОРОТЬБІ ЗІ ЗЛОЧИННІСТЮ}

Однозначність та повнота правового регулювання створення $і$ використання «інформаційно-пошукових систем» Експертної служби МВС Украӥни у боротьбі зі злочинністю залежить від однозначності визначення цього поняття та подальшого його тлумачення. В статті проаналізовано доктринальні підходи до визначення поняття «інформаційно-пошукові системи».

Ключові слова: інформація, інформачійна система, інформачійно-пошукова система (ІПС), автоматизована інформаційно-пошукова система (АІПС), криміналістичні обліки.

DOI 10.34079/2226-3047-2019-9-18-30-40

Вступ. У сучасних умовах практично жодне судово-експертне дослідження не проводиться без інформаційної підтримки, без звернення до новітніх інформаційнопошукових систем. Затребуваність інформаційно-пошукових систем поряд з активним вдосконаленням криміналістичних методів і засобів автоматизації обумовлюють високі темпи розвитку даного напрямку роботи Експертної служби МВС України. Таким чином, особливого теоретичного значення потребує визначення поняття «інформаційно-пошукових систем» Експертної служби МВС України як джерела оперативного одержання інформації про конкретний об'єкт дослідження, а також порядку використання різних сучасних автоматизованих систем і комплексів в цілях ефективного використання їх у боротьбі зі злочинністю.

Проблеми визначення поняття «інформаційно-пошукових систем» Експертної служби МВС України у боротьбі зі злочинністю є одним з найдавніших і недостатньо 
розроблених у криміналістиці, що знайшло своє підтвердження у дослідженнях В. В. Бірюкова, С. О. Бухонського, К. В. Калюги, В. О. Коновалова, Ю. О. Пілюкова, В. М. Шевчука, В. Ю. Шепітько, Б. В. Щура та ін. Однак, зазначені науковці розглядали лише різні аспекти зазначеної проблематики та не піддавали правові положення юридичних актів стосовно визначення поняття «інформаційно-пошукові системи» комплексному системному аналізу, що не сприяло розкриттю повноти його юридичного змісту.

Постановка завдання. Мета дослідження спрямована на доктринальне визначення поняття «інформаційно-пошукових систем» Експертної служби МВС України у боротьбі зі злочинністю.

Результати дослідження. Сьогодні різного роду виявлену, закріплену криміналістично-значиму інформацію фіксують, накопичують, обробляють, систематизують i зберігають у спеціально створених інформаційно-пошукових системах [1, с. 298]. Різноманітна за формами і змістом діяльність Експертної служби MBC України також неможлива без використання інформаційно-пошукових систем, які застосовуються у боротьбі зі злочинністю.

Розгляд поняття інформаційно-пошукових систем Експертної служби МВС України у боротьбі зі злочинністю, доцільно почати з визначення поняття «інформація» та «інформаційні системи», що використовується в юридичному обігу. Так, згідно із ст. 1 Закону України «Про інформацію» [2], під інформацією слід розуміти будь-які відомості та/або дані, які можуть бути збережені на матеріальних носіях або відображені в електронному вигляді. Законом України «Про інформацію» регулюються відносини, що виникають при формуванні та використанні інформаційних систем і банків даних, які направлені на захист інформації і прав суб'єктів, що беруть участь в інформаційних процесах [3, с. 31-35].

Поняття «інформаційні системи» закріплене у Постанові КМУ України «Про затвердження Положення про єдину інформаційну систему Міністерства внутрішніх справ та переліку iї пріоритетних інформаційних ресурсів» [4], згідно якої це багатофункціональна інтегрована автоматизована система, що безпосередньо забезпечує реалізацію функцій її суб'єктів, інформаційну підтримку та супроводження їх діяльності і становить сукупність взаємозв'язаних функціональних підсистем, програмно-інформаційних комплексів, програмно-технічних та технічних засобів телекомунікації, які забезпечують логічне поєднання визначених інформаційних ресурсів, обробку та захист інформації, внутрішню та зовнішню інформаційну взаємодію. Серед суб'єктів єдиної інформаційної системи згідно з наказом є також і Експертна служба МВС України.

Повніше використання спеціальних знань інформаційно-пошукових систем підрозділів Експертної служби та Департаменту інформаційних технологій МВС України регламентується відповідними відомчими нормативно-правовими актами. Підгрунтям для застосування інформаційно-пошукових систем експертної служби МВС України у боротьбі зі злочинністю $\epsilon$ Наказ МВС України «Про затвердження Положення про Експертну службу Міністерства внутрішніх справ України» [5], згідно якого до основних завдань Експертної службі МВС України відносяться забезпечення формування інформаційно-пошукових систем та реалізації їх можливостей в розкритті та розслідуванні злочинів, по використанню в тих же цілях інформаційних ресурсів, зосереджуваних в загально, відомчих i корпоративних інформаційно-пошукових систем, а також практика інформаційного забезпечення розкриття та розслідування злочинів з використанням сучасних інформаційних технологій. 
Відповідно до Наказу МВС України «Про затвердження Інструкції з організації функціонування криміналістичних обліків експертної служби МВС» інформаційнопошукові системи - засновані на базі інформаційних ресурсів (криміналістичних обліків та криміналістичної реєстрації) та створені 3 метою використання їх для запобігання, виявлення, розкриття і розслідування злочинів та інших правопорушень при здійсненні оперативно-розшукової діяльності, дізнання та досудового слідства, а також з метою підвищення рівня інформаційного забезпечення проведення експертних досліджень [6].

Поняття інформаційно-пошукових систем визначено в Наказі МВС України «Про затвердження Положення про Інтегровану інформаційно-пошукову систему органів внутрішніх справ України» [7], згідно якого інтегрована інформаційно-пошукова система органів внутрішніх справ України - це сукупність організаційно-розпорядчих заходів, програмно-технічних та інформаційно-телекомунікаційних засобів, що забезпечують формування та ведення довідково-інформаційних, оперативнорозшукових обліків, авторизований доступ до інформаційних ресурсів ІІПС. Метою створення ІІПС є об'єднання існуючих в органах та підрозділах внутрішніх справ України інформаційних ресурсів в єдиний інформаційно-аналітичний комплекс із використанням сучасних інформаційних технологій, комп'ютерного та телекомунікаційного обладнання для підтримки оперативно-службової діяльності органів і підрозділів внутрішніх справ, суттєвого зміцнення їх спроможності протидії та профілактики злочинності.

Аналіз нормативно-правової бази показав, що Експертна служба МВС України у боротьбі зі злочинністю здебільшого використовує інформаційно-пошукові системи, які забезпечують збирання, збереження та видачу інформації за запитом користувача. Отже, загальна кількість інформаційно-пошукових систем, які створюються та функціонують у підрозділах експертної служби МВС України, мають пряме цільове призначення - сприяти розслідуванню кримінальних проваджень, тобто відносяться до категорії криміналістичних [8].

В юридичній літературі в останні десятиліття з'являються різноманітні точки зору на тлумачення поняття «інформаційно-пошукових систем».

У широкому значенні поняття «інформаційно-пошукові системи», М. С. Полевий, розглядає як криміналістичну інформаційну систему, найважливішими компонентами якої $\epsilon$ людина i його діяльність, пов'язана 3 розкриттям, розслідуванням або попередженням злочинів; криміналістична інформація, що є об'єктом діяльності 3 розкриття і розслідування злочинів; засоби і методи, які використовуються в цілях перетворення криміналістичної інформації у форми, необхідні для прийняття певного рішення [9, с.137]. Отже, метою інформаційно-пошукових систем, як зазначає М.С. Полевий, є отримання різносторонньої і максимально значущої інформації, яка у наступному у сукупності буде необхідною і достатньою для формування системи судових доказів, що забезпечують встановлення і доказування істини у справі [9, с.130]. Слід відзначити, що будь якій інформаційно-пошуковій системі притаманна певна структура інформаційного процесу, яка в узагальненому вигляді подана М.С. Полевим наступним чином: «взаємодіючі об'єкти» - «відображення (зародження інформації)» «сприйняття інформації» - «передача інформації» - «обробка інформації» - «подання інформації споживачу» - «прийняття споживачем рішення» [10, с.27-31], то стає очевидним, що саме стадію обробки інформації, що передує прийняттю рішень, можливо і доцільно перекласти на автоматизовані інформаційно-пошукові системи.

Підтверджує актуальність методологічних проблем визначення поняття «інформаційно-пошукових систем» i H.I. Шахтаріна, зазначаючи: інформаційно- 
пошукові системи - це складний процес застосування комплексу науково-технічних засобів, який тягне за собою не просто інтеграцію юридичних і технічних знань, але i необхідність осмислення на методологічному рівні процесів, що об'єктивно спостерігаються [11, с. 58-62].

А.А. Ексархопуло [12], під інформаційно-пошуковими системами розуміє потрібну для роботи 3 розкриття та розслідування злочинів інформацію, яка систематизується, обробляється і зберігається для використання в сфері боротьби зі злочинністю. Такі системи в вигляді «банків даних» створюються в основному для ведення криміналістичних обліків. 3 цієї позиції, В.В. Бірюкова та І.Н. Горбанєва [13] надають більш деталізоване трактування поняття і зазначають, що для вирішення експертних завдань успішно застосовуються інформаційно-пошукові системи 3 таких напрямів: створення і функціонування банків даних та автоматизованих пошукових систем для роботи з ними; розробка програмних комплексів для забезпечення автоматизації при вирішенні експертних завдань; можливість використання інформації з баз даних інших систем (за наявності підключення до комп'ютерних мереж). Отже, при створенні певних автоматизованих інформаційно-пошукових систем в області судової експертизи, комп'ютеризація відіграє головну роль при здійсненні судової експертизи, що має на меті не тільки фіксацію і первинну обробку експериментальних даних, але й створення програмних комплексів рішення або окремих експертних завдань.

Точка зору таких російських вчених як Г. Г. Зуйкова та Б. А. Красюка на визначення поняття «інформаційно-пошукових систем» наступна: «вони призначені для автоматизації збирання i обробки експериментальних даних, які експерти отримують у процесі фізико-хімічних, грунтознавчих, біологічних та інших досліджень за допомогою методів хроматографії, мас-спектрометрії, ультрафіолетової, інфрачервоної спектроскопії, рентгеноструктурного, рентгеноспектрального, атомного спектрального та інших видів аналізу» [14, с.53-54]. Таким чином, інформаційнопошукова система створена та впроваджена 3 метою подальшого вдосконалення централізованого накопичення, обробки та пошуку довідкової, орієнтувальної та іншої інформації. Їх основу складають криміналістичні обліки, за допомогою яких криміналістично-значима інформація зосереджується i систематизується в автоматизовані інформаційно-пошукові системи у вигляді своєрідних банків даних. В даний час таких обліків налічується близько трьох десятків. Класифікуються вони за різними підставами, а називаються в залежності від виду об'єктів та способів їх реєстрації: алфавітний, дактилоскопічний, стріляних куль і гільз, що вилучаються 3 місць пригод, викрадених номерних речей, підроблених грошових знаків і т.д. Отже, на сьогоднішній день, «інформаційні системи, в тому числі і криміналістичні обліки, що використовуються експертними установами, побудовані за окремими родовими (видовими) і індивідуальними ознаками: подій, людей, матеріалів, речовин, виробів, які мають значення у боротьбі зі злочинністю» [15, с. 44-46].

3 позиції А. Я. Вікарука та А. Ф. Аубакірова «інформаційно-пошукові системи» дозволяють проводити діагностичні та ідентифікаційні дослідження (наприклад, почеркознавчі, порівняння підписів), дактилоскопічні (порівняння слідів рук між собою і сліду з відбитком на дактилокарті), трасологічні (наприклад, за слідом взуття установити його зовнішній вигляд), балістичні, портретні (реконструкція зовнішності особи за черепом, фотосуміщення зображення черепа i фотографіï), складання композиційних портретів тощо. Окремі 3 цих систем використовують і 3 метою криміналістичної реєстрації [18, с. 33; 19, с. 168]. Такої ж точки зору додержується В.В. Кондратьев [20, с. 114] який вважає, що «інформаційно-пошукові системи» у 
проведенні експертних досліджень безпосередньо залежать від застосовуваних науково-технічних засобів або окремих програм виконання допоміжних розрахунків за відповідними формулами та алгоритмами, потрібних для проведення інженернотехнічних експертиз (наприклад, для моделювання умов пожежі чи вибуху), з метою розрахунку кількісних процесів їхнього виникнення i розвитку, коли фізичне моделювання неможливе, а математичне пов'язане зі складними трудомісткими розрахунками.

Інші юристи трактують інформаційно-пошукові системи як інформаційне забезпечення управлінської, наукової, дидактичної діяльності, що пов'язана 3 інформаційним забезпеченням судової експертизи [16, с. 28-30]. 3 цієї позиції, М.Л. Шелухін та О.Н. Шелухін [17, с. 711] пропонують введення в навчальному процесі спеціалізовано-профільних вищих навчальних закладах такої спеціалізації як «безпека інформаційних технологій в правоохоронній сфері», що допоможе у майбутньому застосувати: технології захисту інформації в правоохоронній сфері, інформаційноаналітичне забезпечення правоохоронної діяльності, комп'ютерну експертизу при розслідуванні злочинів.

Поняття «інформаційно-пошукові системи» мають настільки глобальне значення у боротьбі зі злочинністю, що С. Ф. Бичкова пропонує виокремити у загальній теорії судової експертизи «вчення про інформаційні процеси в судовій експертизі» [21, с. 200]. Обгрунтовуючи свою точку зору, С. Ф. Бичкова зазначає, що «з позиції вибраного підходу сама наука про судову експертизу є вищою формою інформаційного знання, управління в досліджуваній галузі є сукупністю дій управляючої системи, які засновані на сигнально-інформаційних процесах; напрогресивніші технології практики судової експертизи базуються на використанні інформаційних систем, заснованих на засобах комп'ютеризації і зв'язку» [21, с. 179]. Підтримуючи позицію С. Ф. Бичкової, слід зазначити, що впровадження інформаційно-пошукових систем у процеси судової експертизи, які базуються на наукових знаннях у галузі криміналістики і $є$ одним із перспективних напрямів подальшого розвитку теорії і практики судової експертизи.

Ю. Ф. Жаріков, Ю. Ю. Орлов, І. А. Струк, Ю. С. Харабуга взагалі пропонують розглядати використання інформаційно-пошукові системи як один із етапів судової експертизи, оскільки без нього вирішення багатьох завдань втрачає свою оперативність. До таких завдань відносять встановлення групової належності об'єктів, а також діагностичні, ідентифікаційні, класифікаційні, ситуаційні завдання [22, с. 458461]. На думку А.Я. Викарука, сьогодні ні в кого не виникає сумнівів, що використання інформаційно-пошукових систем у боротьбі зі злочинністю $\epsilon$ «актуальною проблемою, вирішення якої дозволить значно підвищити продуктивність праці експерта, зробить висновки обгрунтованішими, підніме процес дослідження на якісно новий рівень» [18, с. 31$]$.

Але найбільш значним щодо дослідження поняття «інформаційно-правових систем» Експертної служби МВС України у боротьбі зі злочинністю $є$ доробок українських учених.

У монографії В.В. Бірюкова [23] наведене поняття інформаційно-пошукових систем, під якими розуміється «сприяння впорядкуванню роботи з певною інформацією про об'єкти обліку, їі адресному отриманню й багаторазовому використанню багатьма користувачами». На розвиток сучасних інформаційно-пошукових систем істотно впливає розвиток комп'ютерної техніки та засобів сучасного зв'язку. Під їх впливом відбувається інтеграція окремих обліків у складні інформаційні системи, що дозволяють опрацьовувати та поєднувати різну за формою відображення інформацію, передавати іiі користувачеві у зручній формі на далекі відстані. Основні завдання, що 
вирішуються 3 використанням пошукових інформаційних систем, полягають у забезпеченні збирання, зберігання, опрацювання та видачі інформації користувачеві, яка необхідна йому для вирішення певних завдань, що стоять перед ним.

В. Д. Берназ В. В. Бірюков, А, Ф. Волобуєв [24] розглядають «інформаційнопошукові системи» як основу криміналістичних обліків, що створені і функціонують у правоохоронних органах з метою забезпечення процесу розслідування злочинів певною інформацією про злочини та об'єкти підвищеного криміногенного ризику, яка становить їх масиви. Метою їх створення є безпосереднє сприяння розкриттю злочинів - певна інформаційна система (яка притаманна кожному окремому виду обліку) призначена для виконання у цій діяльності конкретної функції. Такої ж точки зори додержується М. Ю. Будзієвський,О. В. Лускатов, І. В. Пиріг, В. М. Плетенець, К. О. Чаплинський, Ю. А. Чаплинська [25], які під «інформаційно-пошуковими системами» розуміють як складову криміналістичних обліків, що використовуються в розслідуванні злочинів. Отже, як зазначають В.Ю. Шепітько, В.О. Коновалова, В.А. Журавель, В.М. Шевчук, Б.В. Щур «кожний вид криміналістичного обліку - це фактично інформаційно-пошукова система. Тому ведення і використання криміналістичних обліків передбачають широке застосування інформаційних технологій та можливостей комп'ютерної техніки» [26].

В. Ю. Шепітько та Г. К. Авдєєва встановили, що різновидом спеціального програмного забезпечення $€$ автоматизовані інформаційно-пошукові системи, під якими розуміють комплекси програмних засобів та інформаційних продуктів, призначених для збирання, зберігання, пошуку та надання інформації за запитом користувача) [27, с.199]. Подібну точку зору висловлює Іщенко Є.П., який поняття «інформаційно-пошукові системи» визначає як апаратно-програмні комплекси засобів, що дозволяють здійснювати збір, обробку, накопичення криміналістично значущих даних їх видачу на запити споживача [28]. 3 цією метою, як зазначає С.О. Бухонський у своєму дисертаційному дослідженні, така система повинна вирішувати наступні завдання [29, с.66-68]: виконувати інформаційно-технічне забезпечення (ITзабезпечення); формування та забезпечення функціонування інформаційно-облікової пошукової системи; в установленому порядку здійснювати збір, отримання, обробку, узагальнення, накопичення, зберігання, аналіз, надання та використання інформації; забезпечити формування інформаційного масиву за принципом поділу (фізіобіологічних, соціальних та психологічних ознак особи); вдосконалити форму/картку введення/зберігання даних та електронний аналог; забезпечити аналіз та розробку масиву пошукової інформації; мати кодований шлях до доступу (перелік органів, структур,осіб,які мають право доступу); формувати та подавати в установленому порядку аналітичну, статистичну інформацію про злочини; здійснювати контроль за достовірністю та своєчасністю подання інформації.

Так, найбільш продуктивним, на нашу думку, являється підхід Ю. О. Пілюкова, який у своєму дисертаційному дослідженні під поняттям «інформаційно-пошукові системи» розуміє певну систему, що складається з лінгвістичних і програмних засобів, інформаційного забезпечення, а також комплексу технічних засобів для автоматизації збирання, накопичення, обробки, збереження, пошуку і видачі інформації, що використовується для вирішення завдань судово-експертної діяльності [30]. Метою створення інформаційно-пошукових систем в експертних підрозділах ДНДЕКЦ МВС України, на думку Ю.О. Пілюкова, можна об'єднати в сім груп: а) прискорення обігу інформації в стислий термін; б) необхідність одночасного збереження інформації 3 багатьох місць подій; в) оперативне одержання результатів експертних досліджень та їх узагальнення; г) вирішення завдань з обробки великого обсягу даних; д) необхідність 
програмованого вирішення завдань; е) потреби в постійній реєстрації значного обсягу результатів роботи; ж) оперативна взаємодія між службами органів внутрішніх справ; 3) організація централізованого збереження інформації на базі формалізованої мови, здатної здійснювати інформаційні процеси і їхнє корегування для користувача системою; е) забезпечення повною інформацією оперативно-слідчих служб.

Отже, на підставі вищенаведеного, можна зазначити, що інформаційно-пошукові системи в сучасному поданні полягають в поєднанні можливостей людини і технічних засобів по перетворенню (накопичення, обробки та систематизації) криміналістичнозначимої інформації у форми, доступні для іiі користувачів - суб'єктів розкриття i розслідування злочинів. При цьому реалізуються такі важливі властивості будь-якої інформації, як: збереження іiі в часі; не зникає при споживанні користувачем; можливість багаторазового використання; самостійність по відношенню до свого носія; здатність до інтегрування, накопичення, «стиснення».

Висновки. Відповідно до мети дослідження, автор пропонує визначити «інформаційно-пошукові системи» Експертної служби МВС України у боротьбі зі злочинністю - як комплекс науково-технічних засобів, технологій i законодавчо визначеної діяльності співробітників Експертної служби МВС України, спрямованої на збирання, систематизацію, зберігання, аналіз і використання актуальної інформації, що має потенційне значення для забезпечення проведення експертиз, ефективної діяльності з розкриття і розслідуванню злочинів правоохоронними органами, а також для здійснення профілактичної, науково-дослідної, методичної і дидактичної діяльності.

\section{Список використаної літератури}

1.Ковалів М.В. Інформаційно-аналітична робота в ОВС. Проблеми інформаційного забезпечення діяльності практичних підрозділів ОВС та впровадження інформаційних технологій в навчальний процес. Львів, 2004. C. 126-134.; Kovaliv M.V. Informatsiino-analitychna robota v OVS. Problemy informatsiinoho zabezpechennia diialnosti praktychnykh pidrozdiliv OVS ta vprovadzhennia informatsiinykh tekhnolohii $\mathrm{v}$ navchalnyi protses. Lviv, 2004. S. 126-134.

2.Про інформацію: Закон Україні від 02.10.1992 p. № 2657-XI. URL: https://zakon.rada.gov.ua/laws/show/2657-12(дата звернення 14.01.2020); Pro informatsiiu: Zakon Ukraini vid 02.10 .1992 p. № 2657-KhI. URL: https://zakon.rada.gov.ua/laws/show/2657-12(data zvernennia 14.01.2020).

3.Васильєв I. О. Сучасні проблеми інформаційного забезпечення діяльності органів внутрішніх справ. Науковий вісник Дніпропетровського державного університету внутрішніх справ. 2009. № 3.C. 31-35.; Vasyliev I. O. Suchasni problemy informatsiinoho zabezpechennia diialnosti orhaniv vnutrishnikh sprav. Naukovyi visnyk Dnipropetrovskoho derzhavnoho universytetu vnutrishnikh sprav. 2009. № 3.S. 31-35.

4.Про затвердження Положення про єдину інформаційну систему Міністерства

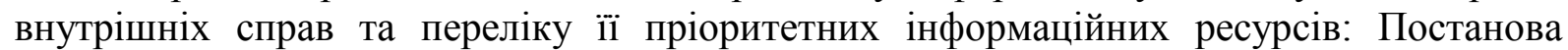
Кабінету Міністрів України від 14.11.2018 p. № 1024. URL: https://zakon.rada.gov.ua/laws/show/1024-2018-\%D0\%BF (дата звернення 14.01.2020); Pro zatverdzhennia Polozhennia pro yedynu informatsiinu systemu Ministerstva vnutrishnikh sprav ta pereliku yii priorytetnykh informatsiinykh resursiv: Postanova Kabinetu Ministriv Ukrainy vid 14.11.2018 r. № 1024. URL: https://zakon.rada.gov.ua/laws/show/1024-2018$\%$ D0\%BF (data zvernennia 14.01.2020).

5.Про затвердження Положення про Експертну службу Міністерства внутрішніх справ України: Наказ Міністерства внутрішніх справ України від 03.11.2015 № 1343. 
URL: https://zakon.rada.gov.ua/laws/show/z1390-15 (дата звернення 14.01.2020); Pro zatverdzhennia Polozhennia pro Ekspertnu sluzhbu Ministerstva vnutrishnikh sprav Ukrainy: Nakaz Ministerstva vnutrishnikh sprav Ukrainy vid 03.11.2015 № 1343. URL: https://zakon.rada.gov.ua/laws/show/z1390-15 (data zvernennia 14.01.2020).

6.Про затвердження Інструкції з організації функціонування криміналістичних обліків експертної служби МВС: Наказ Міністерства внутрішніх справ від 10.09.2009 № 390. URL: https://zakon.rada.gov.ua/laws/show/z0963-09 (дата звернення 14.01.2020); Pro zatverdzhennia Instruktsii z orhanizatsii funktsionuvannia kryminalistychnykh oblikiv ekspertnoi sluzhby MVS: Nakaz Ministerstva vnutrishnikh sprav vid 10.09.2009 № 390 . URL: https://zakon.rada.gov.ua/laws/show/z0963-09 (data zvernennia 14.01.2020).

7.Про затвердження Положення про Інтегровану інформаційно-пошукову систему органів внутрішніх справ України: Наказ Міністерства внутрішніх справ від 12.10.2009 №436 URL: https://zakon.rada.gov.ua/laws/show/z1256-09 (дата звернення 14.01.2020); Pro zatverdzhennia Polozhennia pro Intehrovanu informatsiino-poshukovu systemu orhaniv vnutrishnikh sprav Ukrainy: Nakaz Ministerstva vnutrishnikh sprav vid 12.10.2009 №436 URL: https://zakon.rada.gov.ua/laws/show/z1256-09 (data zvernennia 14.01.2020).

8.Бірюков В. В. та ін.. Інформаційно-довідкове забезпечення кримінальних проваджень [текст] підручн. / за заг. ред. Бірюкова В. В. [В. В. Бірюков, В. Г. Хахановський, В. С. Бондар, С. В. Шалімов. Київ: «ентр учбової літератури», 2014. 288 c.; Biriukov V. V. ta in.. Informatsiino-dovidkove zabezpechennia kryminalnykh provadzhen [tekst] pidruchn. / za zah. red. Biriukova V. V. [V. V. Biriukov, V. H. Khakhanovskyi, V. S. Bondar, S. V. Shalimov. Kyiv: «Tsentr uchbovoi literatury», 2014. $288 \mathrm{~s}$.

9.Полевой Н. С. Криминалистическая кібернетика. 2-е изд. Москва: МГУ, 1989. 328 c.; Polevoi N. S. Krymynalystycheskaia kibernetyka. 2-e yzd. Moskva: MHU, 1989. 328 s.

10.Правовая информатика и кибернетика: учебник / под ред. Н. С. Полевого. Москва: Юрид. лит., 1993. 528 с.; Pravovaya informatika i kibernetika: uchebnik / pod red. N. S. Polevogo. Moskva: Yurid. lit., 1993. 528 s.

11.Шахтарина Н.И. Об актуальности методологических проблем автоматизации судебной экспертизы. Использование математических методов ЭВМ в экспертной практике. Москва: Изд. ВНИИСЭ, 1989. С. 58-62.; Shakhtarina N.I. Ob aktualnosti metodologicheskikh problem avtomatizatsii sudebnoy ekspertizy. Ispolzovanie matematicheskikh metodov EVM v ekspertnoy praktike. Moskva: Izd. VNIISE, 1989. S. $58-62$.

12.Эксархопуло А.А. Криминалистическая техника: учебник и практикум для академического бакалавриата. Москва: Издательство Юрайт, 2019. 349 с.; Eksarkhopulo A.A. Kriminalisticheskaya tekhnika: uchebnik i praktikum dlya akademicheskogo bakalavriata. Moskva: Izdatelstvo Yurayt, 2019. 349 s.

13.Бирюков В.В., Горбанев И.Н. Компьютерные технологии в судебной экспертизе: Матеріали Міжнародної науково-практичної конференції «Сучасні судовоекспертні технології в кримінальному і цивільному судочинстві» (14 - 15 бер. 2003 р.) Харків: Вид-во Нац. ун-ту внутр. справ, 2003. С. 45 - 48.; Biryukov V. V., Gorbanev I. N. Kompyuternye tekhnologii v sudebnoy ekspertize: Materiali Mizhnarodnoï naukovopraktichnoï konferentsiï «Suchasni sudovo-ekspertni tekhnologiï v kriminalnomu i tsivilnomu sudochinstvi» (14 - 15 ber. 2003 r.) Kharkiv: Vid-vo Nats. un-tu vnutr. sprav, 2003. S. 45 48.

14.Основы автоматизации процессов управления: учеб. пособ. / [под ред. Г.Г. Зуйко ва, Б.А. Красюка]. Москва: Академия МВД СССР, 1977. 153 с.; Osnovy 
avtomatizatsii protsessov upravleniya: ucheb. posob. / [pod red. G.G. Zuyko va, B.A. Krasyuka]. Moskva: Akademiya MVD SSSR, 1977. 153 s.

15.Дубровин С. В. Методологические аспекти криминалистической диагностики: монографія. Москва: ЮНИТИ-ДАНА; Закон и право, 2002. 71 с.; Dubrovin S. V. Metodologicheskie aspekti kriminalisticheskoy diagnostiki: monografiya. Moskva: YuNITIDANA; Zakon i pravo, 2002. $71 \mathrm{~s}$.

16.Эджубов Л.Г. Основные направления использования компьютерных технологий. Автоматизация правоохранительных систем: матер. межд. конф. Москва, 1993. C. 28-30.; Edzhubov L.G. Osnovnye napravleniya ispolzovaniya kompyuternykh tekhnologiy. Avtomatizatsiya pravookhranitelnykh sistem: mater. mezhd. konf. Moskva, 1993. S. $28-30$.

17.Шелухин Н.Л. О целесообразности введения в юридических вузах специализации по криминологии и профилактике преступлений / Н. Л. Шелухин, A. Н. Шелухин. DOI 10.17150/2500-4255.2019.13(5).707-717. Всероссийский криминологический журнал 2019. Т. 13, № 5. С. 707-717.; Shelukhin N.L. O tselesoobraznosti vvedeniya $\mathrm{v}$ yuridicheskikh vuzakh spetsializatsii po kriminologii i profilaktike prestupleniy / N. L. Shelukhin, A. N. Shelukhin. DOI 10.17150/25004255.2019.13(5).707-717. Vserossiyskiy kriminologicheskiy zhurnal 2019. T. 13, № 5. C. 707-717.

18.Викарук А.Я. Основные направления применения математических методов и ЭВМ в некоторых родах судебной экспертизы. Проблемы автоматизации создания информационно-поисковых систем и применение математических методов в судебной экспертизе. Москва: Изд. ВНИИСЭ, 1987. С. 31-38.; Vikaruk A.Ya. Osnovnye napravleniya primeneniya matematicheskikh metodov i EVM v nekotorykh rodakh sudebnoy ekspertizy. Problemy avtomatizatsii sozdaniya informatsionno-poiskovykh sistem i primenenie matematicheskikh metodov v sudebnoy ekspertize. Moskva: Izd. VNIISE, 1987. S. 31-38.

19.Аубакиров А.Ф. Основные принципы организации автоматизированного производства експертиз. Использование математических методов ЭВМ в экспертной практике. Москва: Изд. ВНИИСЭ, 1989. С. 62 - 66.; Aubakirov A.F. Osnovnye printsipy organizatsii avtomatizirovannogo proizvodstva ekspertiz. Ispolzovanie matematicheskikh metodov EVM v ekspertnoy praktike. Moskva: Izd. VNIISE, 1989. S. 62 - 66.

20.Кондратьев В.В. Возможности автоматизации решения задач по взрывотехнической экспертизе: Труды международной конференции «Информатизация правоохранительных систем». Москва, 1993. C. 114.; Kondratev V.V. Vozmozhnosti avtomatizatsii resheniya zadach po vzryvotekhnicheskoy ekspertize: Trudy mezhdunarodnoy konferentsii «Informatizatsiya pravookhranitelnykh sistem». Moskva, 1993. S. 114.

21.Бычкова С.Ф. Становление и тенденции развития науки о судебной экспертизе: учеб. пособ. Алма-Ата, 1994. 340 c.; Bychkova S.F. Stanovlenie i tendentsii razvitiya nauki o sudebnoy ekspertize: ucheb. posob. Alma-Ata, 1994. 340 s.

22.Проблемы автоматизации экспертных исследований / [Жариков Ю. Ф., Орлов Ю. Ю., Струк И. А., Харабуга Ю. С.] // Теорія та практика судової експертизи і криміналістики: матер. міжн. наук.-практ. конф. / Харківський науково-дослідний інститут судових експертиз ім. засл. проф. М. С. Бокаріуса. Харків: Право, 2002. Вип. 2. 656 c. Problemy avtomatizatsii ekspertnykh issledovaniy / [Zharikov Yu. F., Orlov Yu. Yu., Struk I. A., Kharabuga Yu. S.] // Teoriya ta praktika sudovoï ekspertizi i kriminalistiki: mater. mizhn. nauk.-prakt. konf. / Kharkivskiy naukovo-doslidniy institut sudovikh ekspertiz im. zasl. prof. M. S. Bokariusa. Kharkiv: Pravo, 2002. Vip. 2. 656 s. 
23.Бірюков В.В. Теоретичні основи інформаційно-довідкового забезпечення розслідування злочинів: Монографія / Луган. держ. ун-т внутр. справ ім. Е.О. Дідоренка. Луганськ: РВВ ЛДУВС ім. Е.О. Дідоренка,2009. 664 с.; Biriukov V.V. Teoretychni osnovy informatsiino-dovidkovoho zabezpechennia rozsliduvannia zlochyniv: Monohrafiia / Luhan. derzh. un-t vnutr. sprav im. E.O. Didorenka. Luhansk: RVV LDUVS im. E.O. Didorenka,2009. 664 s.

24.В. Д. Берназ И ДР.. Криміналістка: підручник / [В. Д. Берназ В. В. Бірюков, А. Ф. Волобуєв; за заг. ред. А. Ф. Волобуєва; МВС України, Харк. над. ун-т внутр. справ. Харків; ХНУВС,2011. 666 c.; V. D. Bernaz Y DR.. Kryminalistka: pidruchnyk / [V. D. Bernaz V. V. Biriukov, A. F. Volobuiev; za zah. red. A. F. Volobuieva; MVS Ukrainy, Khark. nad. un-t vnutr. sprav. Kharkiv; KhNUVS,2011. 666 s.

25.Будзієвський М.Ю. Криміналістика (курс лекцій): навчальний посібник / М. Ю. Будзієвський,О.В.Лускатов, І.В.Пиріг, В.М.Плетенець, К. О. Чаплинський, Ю. А. Чаплинська. Дніпро: Дніпроп. держ. ун-т внутр. справ, 2013. 397 с.; Budziievskyi M.Iu. Kryminalistyka (kurs lektsii): navchalnyi posibnyk / M. Yu. Budziievskyi,O. V. Luskatov, I. V. Pyrih, V. M. Pletenets, K. O. Chaplynskyi, Yu. A. Chaplynska. Dnipro: Dniprop. derzh. un-t vnutr. sprav, 2013. 397 s.

26.Криміналістика: підручник / В.Ю. Шепітько, В.О. Коновалова, В.А. Журавель, В.М. Шевчук, Б.В. Щур [та ін.]: за ред. В.Ю. Шепітька. 5-те вид. перероб. та допов. Київ: Ін Юре, 2016. 640 с.; Kryminalistyka: pidruchnyk / V.Iu. Shepitko, V.O. Konovalova, V.A. Zhuravel, V.M. Shevchuk, B.V. Shchur [ta in.]: za red. V.Iu. Shepitka. 5-te vyd. pererob. ta dopov. Kyiv: In Yure, 2016. $640 \mathrm{~s}$.

27.Шепітько В.Ю., Авдєєва Г.К. Інформаційні технології в криміналістиці та слідчій діяльності. Питання боротьби зі злочинністю : зб. наук. пр. Харків, 2010. Вип. 19. C. 194-203.; Shepitko V.Iu., Avdieieva H.K. Informatsiini tekhnolohii v kryminalistytsi ta slidchii diialnosti. Pytannia borotby zi zlochynnistiu : zb. nauk. pr. Kharkiv, 2010. Vyp. 19. S. 194-203.

28.Ищенко Е.П. Понятое и структура информационного обеспечения следственной деятельноста. Вісник Луганського державного університету внутрішніх справ імені. Е.О Дідоренка. Спец.випуск. 2008. № 5. Ч.1. С. 3-12. Ishchenko Ye.P. Ponyatoe i struktura informatsionnogo obespecheniya sledstvennoy deyatelnosta. Visnik Luganskogo derzhavnogo universitetu vnutrishnikh sprav imeni. Ye.O Didorenka. Spets.vipusk. 2008. № 5. Ch.1. S. 3-12.

29.Бухонський С.О. Інформаційно-аналітичне забезпечення початкового етапу досудового розслідування: дис. канд. юрид. наук : 12.00 .09 ; Класичний приватний університет. Запоріжжя, 2017. 270 c.; Bukhonskyi S.O. Informatsiino-analitychne zabezpechennia pochatkovoho etapu dosudovoho rozsliduvannia: dys. kand. yuryd. nauk : 12.00.09; Klasychnyi pryvatnyi universytet. Zaporizhzhia, 2017. $270 \mathrm{~s}$.

30.Пілюков Ю.О. використання інформаційних систем в експертних підрозділах MBC України: дис. канд. юрид. наук : 12.00.09; Київ, 2005. 22 с.; Piliukov Yu.O. vykorystannia informatsiinykh system v ekspertnykh pidrozdilakh MVS Ukrainy: dys. kand. yuryd. nauk : 12.00.09; Kyiv, 2005. $22 \mathrm{~s}$.

\section{N. Mitko \\ CONCEPTS OF INFORMATION AND SEARCH SYSTEMS OF THE EXPERT SERVICE OF THE MINISTRY OF THE UKRAINE IN THE FIGHT AGAINST CRIME}


The uniqueness and completeness of legal regulation of the creation and use of «information retrieval systems» of the Expert Service of the Ministry of Internal Affairs of Ukraine in the fight against crime depends on the uniqueness of the definition of this concept and its further interpretation.The article analyzes doctrinal approaches to defining the concept of «information retrieval systems».

Key words: information, information system, information retrieval system (IMS), automated information retrieval system (AIPS), forensic records.

Стаття надійшла до редакції 09.10.2019 р.

\section{УДК 346.12}

\section{А.А. Попов, \\ Е.Л. Шевченко.}

\section{ЗОВНШШНЯ ТРУДОВА МІГРАЦІЯ І УКРАЇНСЬКЕ ПРАВО: ВИМОГИ І СЬОГОДЕННЯ}

У статті зроблено аналіз співвідношення правового регулювання трудової міграчії з України з потребами украӥнських національних інтересів. Звернуто увагу на те, щуо положення двосторонніх міжнародних угод Украӥни з іншими краӥнами в сфері взаємного працевлаштування не відповідають вимогам сучасності, а також не враховують позитивний досвід іноземних краӥн.

Висунута пропозичія про необхідність забезпечення прав украӥнських трудових мігрантів за кордоном нормами не тільки трудового права, а ци циивільного $i$ фінансового, а також розширення кількості $і$ змісту відповідних міжнародних угод Украӥни з іншими краӥнами.

Ключові слова: зовнішня трудова міграчія; легальна міграчія; нелегальна міграчія; підхід спільного розвитку; репатріачія навиків та знань.

DOI 10.34079/2226-3047-2019-9-18-40-46

Актуальність теми. Україна протягом останніх років стала активним учасником процесів міжнародної трудової міграції. У 1991 році була зруйнована монополія держави на працевлаштування українських громадян за кордоном, більша відкритість українського суспільства призвела до активізації міжнародного трудового обміну 3 країнами далекого зарубіжжя. Ця ситуація створила значну кількість економічних, соціальних, організаційних, правових та інших проблем, багато з яких остаточно ще не усвідомлені суспільством і не досліджені фахівцями.

Мета статті. Авторами висвітлюється зовнішня міграційна ситуація України, аналізується стан іiї правового регулювання, а також найбільш типові міграційні правові документи.

Виклад основного матеріалу. Зацікавленість роботодавців у залученні іноземної робочої сили очевидна і пояснюється можливістю прийняти на роботу кваліфікованих фахівців, які погоджуються на більш низький рівень заробітної плати і соціальних гарантій. В даний час склався стійкий попит на робочу силу з України. При цьому, збільшилась кількість випадків порушення прав i свобод українських громадян, зобов'язань за трудовим контрактом з боку іноземних роботодавців. Запобігти цьому, як вважає Г. О. Денисова, можна шляхом правильної організації і чіткого 